\title{
HEINONLINE
}

Citation: 57 U. Chi. L. Rev. 12601990

Content downloaded/printed from HeinOnline (http://heinonline.org)

Thu Jul 26 13:51:22 2012

-- Your use of this HeinOnline PDF indicates your acceptance of HeinOnline's Terms and Conditions of the license agreement available at http://heinonline.org/HOL/License

-- The search text of this PDF is generated from uncorrected OCR text.

-- To obtain permission to use this article beyond the scope of your HeinOnline license, please use:

https://www.copyright.com/ccc/basicSearch.do?

\&operation $=$ go\&search Type $=0$

\&lastSearch $=$ simple\&all $=$ on\&titleOrStdNo $=0041-9494$

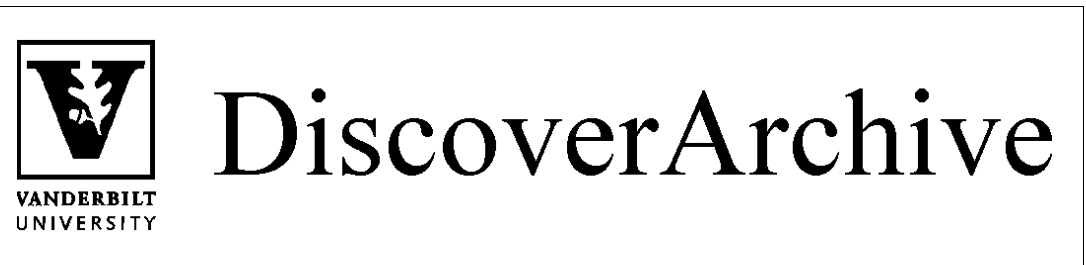

Retrieved from DiscoverArchive,

Vanderbilt University's Institutional Repository

Sherry, S., The Eleventh Amendment and Stare Decisis: Overruling

Hans v Louisiana, 57 U. Chi. L. Rev. 12601990 


\title{
CORRESPONDENCE ON THE ELEVENTH AMENDMENT
}

\section{The Eleventh Amendment and Stare Decisis: Overruling Hans $v$ Louisiana}

\author{
Suzanna Sherry $\dagger$
}

There is currently a dispute raging about the meaning of the Eleventh Amendment, which protects states from suits in federal court. The language of that amendment appears to deny federal jurisdiction only over suits brought against states by citizens of another state, ${ }^{1}$ but the Court, since its 1890 decision in Hans $v$ Louisiana, has interpreted the amendment to bar all federal suits against states, including those brought by a state's own citizens. ${ }^{2}$ Thus, under current doctrine, the Eleventh Amendment bars all suits brought against a state in federal court, regardless of the citizenship of the plaintiff or the basis for jurisdiction. ${ }^{3}$

$\dagger$ Professor of Law, University of Minnesota. I am grateful to John J. Cound, Paul H. Edelman, Daniel A. Farber, and Philip P. Frickey for their helpful comments on earlier drafts of this essay.

1 The Eleventh Amendment states: "The Judicial power of the United States shall not be construed to extend to any suit in law or equity, commenced or prosecuted against one of the United States by Citizens of another State, or by Citizens or Subjects of any Foreign State." US Const, Amend XI.

${ }^{2} 134$ US 1, 21 (1890). The Court has mitigated the harshness of this result by extending the protection of the Eleventh Amendment only to unconsenting states, not state officials. An individual may still sue a state officer for official actions, as long as the requested relief does not implicate retrospective payments from the state treasury. See $E x$ parte Young, 209 US 123, 155-56 (1908); Edelman $v$ Jordan, 415 US 651, 677 (1974). Moreover, the Court has held that states may consent to suit in federal court, see, for example, Port Authority Trans-Hudson Corp. v Feeney, $110 \mathrm{~S} \mathrm{Ct}$ 1868, 1872 (1990); Fla. Dept. of Health v Fla. Nursing Home Ass'n, 450 US 147, 149-50 (1981), and that Congress has the power to abrogate state sovereign immunity and thus to strip states of their Eleventh Amendment protection. See, for example, Pennsylvania v Union Gas Co., $109 \mathrm{~S}$ Ct 2273, 2284 (1989).

${ }^{3}$ Technically, Hans relied on prior precedent, itself somewhat ambiguous, to hold that the Eleventh Amendment was not himited to cases brought under diversity jurisdiction. See 
Recently, however, some judges and scholars-including Professor William Fletcher in previous issues of the Review-have suggested that the amendment should prohibit only those suits brought in diversity. ${ }^{4}$ If there is an alternative basis for federal jurisdiction, such as the existence of a federal question, they would interpret the language and history of the amendment to permit the suit. Thus, the proponents of this "diversity explanation" maintain that Hans must be overruled.

But even if the diversity explanation is correct, there is still the problem of stare decisis-a problem that the proponents of the

Louisiana v Jumel, 107 US 711, 720-21, 727-28 (1883) and In re Ayers, 123 US 443, 446, $461,502-03$ (1887). In these cases, the plaintiffs were either foreign citizens (Ayers) or citizens of another state (Jumel), but both raised federal questions. The Hans court held that Jumel and Ayers had already determined that non-citizen plaintiffs could not sue states in federal courts, whether based on state-citizen diversity or federal question jurisdiction, 134 US at 10, and went on to discuss the lack of significance of the citizenship of the parties. The only new holding of Hans, then, was its extension of the amendment to cases brought by citizens of the defendant state. Nevertheless, the modern practice is to cite Hans as the definitive precedent on both questions: first, that the Eleventh Amendment protects states from all suits in federal courts brought by non-citizen plaintiffs, even if there exists a federal question, and, second, that the amendment protects states from all suits brought by citizen plaintiffs.

- See William A. Fletcher, Exchange on the Eleventh Amendment, 57 U Chi L Rev 131 (1990), and The Diversity Explanation of the Eleventh Amendment: A Reply to Critics, 56 U Chi L Rev 1261 (1989). See also Fletcher's first work on the subject, A Historical Interpretation of the Eleventh Amendment: A Narrow Construction of an Affirmative Grant of Jurisdiction Rather than a Prohibition Against Jurisdiction, 35 Stan L Rev 1033 (1983). Other books and articles favoring the diversity explanation include John V. Orth, The Judicial Power of the United States: The Eleventh Amendment in American History 12-29 (Oxford, 1987); Akhil Reed Amar, A Neo-Federalist View of Article III: Separating the Two Tiers of Federal Jurisdiction, 65 BU L Rev 205, 238-54 (1985); Akhil Reed Amar, Of Sovereignty and Federalism, 96 Yale L J 1425 (1987); John J. Gibbons, The Eleventh Amendment and State Sovereign Immunity: A Reinterpretation, 83 Colum L Rev 1889, 1893-94 (1983); and Vicki C. Jackson, The Supreme Court, the Eleventh Amendment, and State Sovereign Immunity, 98 Yale L J 1, 4 (1988). See also Martha A. Field, The Eleventh Amendment and Other Sovereign Immunity Doctrines: Part One, $126 \mathrm{U} \mathrm{Pa} \mathrm{L} \mathrm{Rev} \mathrm{515,} 517$ (1978) (suggesting implicitly that state sovereign immunity may have its source in common law rather than the Eleventh Amendment).

For support for the diversity explanation among four dissenting Justices of the Supreme Court (Brennan, Marshall, Blackmun, and Stevens), see Welch $v$ Texas Dept. of Highways, 483 US 468, 496-97 (1987) (Brennan dissenting); Atascadero State Hospital v Scanlon, 473 US 234, 258-59 (1985) (Brennan dissenting).

For criticism of the diversity explanation, see, for example, Lawrence C. Marshall, Fighting the Words of the Eleventh Amendment, 102 Harv L Rev 1342, 1346-47 (1989); William P. Marshall, The Diversity Theory of the Eleventh Amendment: A Critical Evaluation, 102 Harv L Rev 1372, 1375 (1989); and Calvin R. Massey, State Sovereignty and the Tenth and Eleventh Amendments, 56 U Chi L Rev 61, 64-65 (1989).

The most recent scholarly exchange of views between proponents and critics is Calvin R. Massey, William P. Marshall, Lawrence C. Marshall, and William A. Fletcher, Exchange on the Eleventh Amendment, $57 \mathrm{U}$ Chi L Rev 118 (1990). 
theory have so far neglected. ${ }^{5}$ Hans has been the law for a century. Moreover, as the Supreme Court pointed out in 1987, Eleventh Amendment jurisprudence is not a clean slate: overruling Hans would require overruling at least seventeen other cases relying on it. "Thus, even assuming that Hans was incorrectly decided, should the doctrine of stare decisis prevent the Court from overruling it?

This essay attempts to provide an answer. Part I discusses the doctrine of stare decisis and the general conditions that justify departing from precedent. Part II applies that doctrine to Hans. In particular, Part II suggests that legal circumstances since 1890 have changed so significantly that adherence to Hans is no longer justified.

It is an oft-repeated maxim that courts will not rigidly apply stare decisis in constitutional cases. ${ }^{7}$ Nevertheless, the Court has noted that "any departure from the doctrine of stare decisis demands special justification." It is particularly necessary to justify overruling precedent as well-settled and consistently applied as Hans. ${ }^{9}$

Even, or perhaps especially, in the constitutional context, departures from stare decisis endanger the perceived legitimacy of

- There have been occasional attempts to finesse the question. Vicki Jackson has suggested that overruling Hans would not affect subsequent caselaw, and thus that stare decisis is not a serious problem. See Jackson, 98 Yale $L J$ at 119-24 (cited in note 4). Justice Brennan has suggested in a footnote that Hans is ripe for overruling because it has led to "erratic and irrational results" and to "inconsistencies in constitutional interpretation." Welch, 483 US at 519-20 n 19 (Brennan dissenting). No further elaboration has been forthcoming from either Justice Brennan or his academic supporters.

${ }^{6}$ Welch, 483 US at $495 \mathrm{n} 27$ (1987); see also id at 496 (Scalia concurring) (statutes enacted since Hans assumed sovereign immunity).

' See, for example, United States $v$ Scott, 437 US 82, 101 (1978), in which the Court noted:

We recognize the force of the doctrine of stare decisis, but we are conscious as well of the admonition of Mr. Justice Brandeis: "[I]n cases involving the Federal Constitution, where correction through legislative action is practically impossible, this Court has often overruled its earlier decisions. The Court bows to the lessons of experience and the force of better reasoning, recognizing that the process of trial and error, so fruitful in the physical sciences, is appropriate also in the judicial function."

(quoting Burnet $v$ Coronado Oil \& Gas Co., 285 US 393, 406-408 (1932) (Brandeis dissenting)).

${ }^{8}$ Arizona $v$ Rumsey, 467 US 203, 212 (1984). Accord Patterson v McLean Credit Union, 109 S Ct 2363, 2370 (1989); Garcia v San Antonio Metropolitan Transit Authority, 469 US 528, 559 (1985) (Powell dissenting). See also Akhil Reed Amar, Our Forgotten Constitution: A Bicentennial Comment, 97 Yale L J 281, 294 n 51 (1987).

- See, for example, W. Marshall, 57 U Chi L Rev at 127 (cited in note 4). 
the Court. By giving the impression that one group of Justices is merely substituting its own will for that of an earlier group of Justices, overruling well-established precedent undermines the public perception of the Court as a neutral and disinterested decisionmaker. ${ }^{10}$ Frequent or careless overruling also contributes to instability and uncertainty in the law, and this is no less true of constitutional law than it is of statutory or common law. ${ }^{11}$ The need for stability counsels in favor of retaining Hans: states have relied on its protections for a century, lower courts have developed experience in identifying and applying the complex rules it has generated, and the Supreme Court has consistently adhered to it.

The strongest justification for relaxing stare decisis requirements in constitutional cases is that constitutional decisions are beyond the reach of congressional repair. ${ }^{12}$ Yet this justification is entirely absent in the case of the Eleventh Amendment. Indeed, Congress has the power to abrogate state immunity and to subject even unconsenting states to suits in federal court. ${ }^{13}$ Congress therefore has the power virtually to eliminate the Hans doctrine. The Court has recently held in another context that the primary protection of state sovereignty is state representation in Congress, ${ }^{14}$ further undermining any justification for the Court to strip states of existing-albeit judicially created-protections. Thus, the considerations favoring stare decisis are stronger in Hans than in most constitutional cases.

Stare decisis is not an absolute doctrine in either constitutional or non-constitutional cases, however. It does not require

10 See Jerold H. Israel, Gideon v. Wainwright: The "Art" of Overruling, 1963 S Ct Rev 211, 216-19; Earl M. Maltz, Some Thoughts on the Death of Stare Decisis in Constitutional Law, 1980 Wis L Rev 467, 483-84; Henry Paul Monaghan, Stare Decisis and Constitutional Adjudication, 88 Colum L Rev 723, 752-53 (1988); Frederick Schauer, Precedent, 39 Stan L Rev 571, 600 (1987); and Note, Constitutional Stare Decisis, 103 Harv L Rev 1344, 1349-55 (1990). See also Garcia, 469 US at 559 (1985) (Powell dissenting); Mapp v Ohio, 367 US 643, 677 (1961) (Harlan dissenting).

Henry Monaghan has suggested that the danger is particularly acute in the context of the Court's reputation before the elite or scholarly class rather than before the general public. Monaghan, 88 Colum $\mathrm{L}$ Rev at 749 . This raises the intriguing possibility that because legal academics as a group are thought to be more liberal than the current Supreme Court, overruling Hans $v$ Louisiana will please rather than disappoint the Court's relevant audience. See, for example, Robert Bork, The Tempting of America: The Political Seduction of the Law 5-6 (Macmillan, 1990). Nevertheless, such a result-oriented analysis is an insufficient basis for justifying the overruling of a venerable case.

1 See Maltz, 1980 Wis L Rev at 472-78 (cited in note 10); Monaghan, 88 Colum L Rev at 749-51 (cited in note 10).

12 See Maltz, 1980 Wis L Rev at $468-72$ (cited in note 10 ).

ss See cases cited in note 2 .

14 See Union Gas, $109 \mathrm{~S}$ Ct at 2284; Garcia, 469 US at 547-55. 
"slavish adherence to authority where new conditions require new rules of conduct."1s While the Court has not been entirely clear on the conditions that justify a departure from prior precedent, scholars have identified three important concerns: 1) changed circumstances; 2) difficulty in applying the precedent; and 3) later cases inconsistent with the precedent. ${ }^{16}$ The first and third strongly weigh in favor of overruling Hans. ${ }^{17}$

Changed circumstances justify overruling prior precedent in two related ways. First, such changes "undermine[] the basis for the overruled decision."18 Second, "an opinion emphasizing the changed circumstances naturally will contain the countersuggestion that ... the former Court might well have decided differently if confronted with today's conditions."19 Therefore, in examining the development of the law since Hans, I will focus on the extent to which the case depended for its legitimacy and correctness on surrounding legal circumstances that have changed.

Inconsistent subsequent law also justifies overruling precedent. In some cases, these inconsistencies can be so blatant as to justify a conclusion that the Court has already overruled the precedent; formal overruling is merely the coup de grace. In many cases, however, the inconsistency is more subtle. Indeed, even inconsistencies in areas of law that only indirectly relate to the original precedent rather than directly imphcating it may justify a departure from stare decisis where the later cases "impair [the] authority" of the original precedent. ${ }^{20}$ Thus a second factor I will examine is the extent to which later cases in related areas have left Hans without a constitutional anchor.

${ }^{16}$ Mahnich v Southern Steamship Co., 321 US 96, 113 (1944) (Roberts dissenting).

${ }^{16}$ See Philip P. Frickey, Stare Decisis in Constitutional Cases: Reconsidering National League of Cities, 2 Const Comm 123, 128 (1985); Israel, $1963 \mathrm{~S}$ Ct Rev at 219-226 (cited in note 10); Note, 103 Harv L Rev at 1346-47 (cited in note 10).

${ }^{17}$ Justice Brennan's suggestion that Hans has created "irrational" results and constitutional "inconsistencies" appears in context to be primarily a charge that the Hans doctrine has become difficult to apply. Welch, 483 US at 519-20 n 19 (Brennan dissenting). He notes that the rules of sovereign immunity are a "crazy-quilt pattern." Id. In fact, although the various rules are complex to learn, they are relatively simple to apply. See text at notes 2-3. This is in stark contrast to the situation in Garcia, 469 US at 546-47, where the "governmental functions" test of National League of Cities v Usery, 426 US 833 (1976), had proved impossible to apply and thus was overruled.

${ }^{18}$ Frickey, 2 Const Comm at 128 (cited in note 16).

29 Israel, $1963 \mathrm{~S} \mathrm{Ct}$ Rev at 221 (cited in note 10).

${ }^{20}$ Id at 223, quoting Gore v United States, 357 US 386, 388 (1958). See also Mapp, 367 US at 653-55 (using developments in related areas to justify overruling prior precedent). 
At the time Hans was decided, it was not surprising that the Court refused to draw any distinction between diversity and federal question jurisdiction when it examined the language of the Eleventh Amendment. In 1890, there was indeed little difference between the two bases of jurisdiction in terms of the substantive law applied by the Court. By then, the federal courts interpreted the 1842 decision in Swift $v$ Tyson ${ }^{21}$ to require the apphication of federal law to both diversity and federal question actions. The only difference between a suit brought in diversity and a suit brought under federal question jurisdiction was the source of the governing federal substantive law: federal courts applied federal common law to diversity actions and either federal common law or federal statutory or constitutional law to federal question actions.

The Court originally limited the Swift doctrine to diversity cases involving the "general common law" or non-statutory law, which Swift held to encompass commercial law. ${ }^{22}$ During the first half of the nineteenth century-even after Swift-the federal courts routinely applied state law in diversity cases involving "local" common law. ${ }^{23}$ The Supreme Court also concluded that state judicial interpretations of state statutes, as opposed to common law pronouncements, were still binding on federal courts in diversity cases. As late as 1862, the Court held that " $[t]$ he construction given to a statute of a State by the highest judicial tribunal of such State, is regarded as a part of the statute, and is as binding upon the Courts of the United States as the text."24 It added that this rule would apply even where a state court changed its interpretation of a statute: in that case the federal courts "w[ould] follow the latest settled adjudications. ${ }^{.25}$ In fact, the Court overruled its own interpretation of state law if the state court subsequently adopted a different interpretation. ${ }^{26}$

2141 US 1 (1842).

22 Id at 18-19.

${ }^{23}$ See generally, Randall Bridwell and Ralph Whitten, The Constitution and the Common Law: The Decline of the Doctrines of Separation of Powers and Federalism 112-14 (Lexington Books, 1977); William A. Fletcher, The General Common Law and Section 34 of the Judiciary Act of 1789: The Example of Marine Insurance, 97 Harv L Rev 1513, 1531-38 (1984).

${ }^{34}$ Leffingwell $v$ Warren, 67 US 599, 603 (1862).

25 Id.

${ }^{20}$ Green $v$ Lessee of Neal, 31 US 291, 297-98 (1832). Although the Court decided this case prior to Swift, it was consistent with Swift: the Court stressed that the question was one of property rights, quintessentially a question of local law. 
By the late nineteenth century, however, the Court had so expanded the general law doctrine of Swift that a federal court sitting in diversity was free to ignore definitive state decisions involving both "local" law and state statutory law, including state constitutional law. The Court began to chip away at the settled general law limitations on Swift as early as $1864 .{ }^{27}$ Historian Carl Swisher has noted that during the second half of the nineteenth century, "[t]he Supreme Court began to challenge not merely state court interpretations of the common law but also state statutes violating principles or practices in which the Court believed."28 Justice Field, writing in 1893, complained that "learned judges have fallen into the habit of repeating [the Swift general law] doctrine as a convenient mode of brushing aside the law of a State in conflict with their views."

This process of expanding the definition of "general law" was most striking in the context of state constitutional rulings. A series of cases interpreting state bond issues illustrates the growth of federal common law during this period. The Court first held that it would no longer be bound by state decisions reversing earlier state interpretations, regardless of the character of the state law at issue. In Gelpcke $v$ Dubuque, the Court confronted a situation in which the Iowa Supreme Court had recently overruled a series of earlier Iowa cases. ${ }^{30}$ In its latest pronouncement, the state supreme court had held that state legislation authorizing the issuance of railroad bonds violated the Iowa constitution. ${ }^{31}$ The United States Supreme Court nevertheless upheld the validity of the bonds, holding that it would not "follow every such oscillation" in the state courts because the bonds had been issued and purchased in reliance upon

${ }^{27}$ Gelpcke $v$ Dubuque, 68 US 175 (1864). Several years earlier, however, the Court had refused to overturn its own interpretation of state law in the face of a subsequent conficting state interpretation. See Rowan v Runnels, 46 US 134 (1847), in which the Court adhered to Groves v Slaughter, 40 US 449 (1841) (interpreting Mississippi constitution not to prohibit sale of slaves), despite an intervening state decision construing the state constitution differently. Thus the erosion of the limitations on Swift may have begun only a few years after Swift itself. The major shift did not occur until the 1870s and 1880s, however, as described in the text.

${ }^{28}$ Carl B. Swisher, 5 History of the Supreme Court of the United States 333 (Macmillan, 1974). See also Charles Fairman, 6 History of the Supreme Court of the United States: Reconstruction and Reunion 918-1116 (Macmillan, 1971).

${ }^{29}$ Baltimore \& Ohio R.R. Co. v Baugh, 149 US 368, 401 (1893) (Field dissenting).

so 68 US 175 (1864).

31 Iowa ex rel Burlington \& Missouri River R.R. Co. v County of Wapello, 13 Iowa 388 (1862). 
the earlier state cases upholding the constitutionality of bond legislation. ${ }^{32}$

The Court's opinion in Gelpcke, however, also contained the seeds of further expansion of federal authority under diversity jurisdiction. The Court noted-in dicta that would later become law-that it rejected the latest Iowa pronouncement in part because the earlier decisions it overruled were "sustained by reason and authority" and were "in harmony with the adjudications of sixteen States of the Union." "ss Only seven years later, the Court began moving away from the idea that only "oscillations" in the state court would justify ignoring state interpretations of state constitutions. In City $v$ Lamson, the Court upheld the validity of railroad bonds under the Wisconsin Constitution, despite recent state decisions holding such bonds unconstitutional. ${ }^{34}$ The Court purportedly relied on Gelpcke, noting that the bonds had been issued and purchased in reliance upon earlier Wisconsin decisions upholding the constitutionality of bond legislation. ${ }^{35}$ In fact, however, the only Wisconsin decisions addressing the constitutionality of bonds cited by the Court were handed down several years after the issuance of the bonds in question. ${ }^{36}$ Thus, in reality, Gelpcke was not controlling.

Despite its misstatement of the facts, Lamson technically remained within the limits of Gelpcke, at least in its statement of the law. Later cases, however, ignored the Gelpcke rule altogether and refused to follow state decisions even where there had been no prior ruling and thus no "oscillation" or overruling.

In 1873 , the Court essentially opened the door for the federal courts to consider any state constitutional ruling a matter of "gen-

${ }^{32} 68$ US at 205-06. See also Douglass $v$ County of Pike, 101 US 677, 679 (1880) ("The question presented ... . is not so much whether these late decisions are right, as whether they should be followed in cases having reference to bonds put out and in the hands of innocent purchasers when they were announced.").

One historical explanation for Gelpcke and its progeny turns on the unfairness of the retroactive state court decisions. Although limiting decisions to prospective effect is common today, it was much less accepted in the nineteenth-century age of common law formalism. See, for example, William N. Eskridge, Jr. and Philip P. Frickey, Cases and Materials on Legislation: Statutes and the Creation of Public Policy 264-77 (West, 1988). Thus the Supreme Court in cases like Gelpcke faced what it considered the unpalatable alternative of creating unfair surprise and cbaos among bondholders through retroactive rulings. Another possibility, apparently not considered by the Court in these cases, would have been to invalidate the bond abrogations as a violation of the federal Contract Clause.

ss Gelpcke, 68 US at 205-06.

s4 76 US $477,485-86$ (1870).

ss Id.

36 For criticism of the Supreme Court's treatment of these two Wisconsin cases, see also Fairman, 6 History of the Supreme Court at 1028-31 (cited in note 28). 
eral law" within the Swift doctrine. In Whiting $v$ Fond du Lac Railroad Co., the Wisconsin Supreme Court had declared that the railroad bond legislation violated the state constitution on the ground that such bonds permitted taxation for a private, rather than a public, purpose. ${ }^{37}$ In Olcott $v$ Supervisors, however, the United States Supreme Court rejected the Whiting rule and upheld the issuance of the bonds. ${ }^{38}$ The Court first noted the general rule that federal courts would follow state court decisions "respecting the construction of their own constitutions and laws." The Court went on, however, to declare that the question of the uses for which taxes could be levied was "not one of [state constitutional] interpretation or construction" but was rather "a question of general law." 40 Thus, after Olcott, the federal courts no longer needed the Gelpcke oscillation doctrine to reject state interpretations of state constitutions.

Indeed, during the 1870s and 1880s, the Supreme Court frequently refused to follow even state court decisions of first impression." The Court simply made its own decision about what the state constitution meant. Sometimes it combined its own analysis of the question with a perfunctory bow to Gelpcke. ${ }^{42}$ At least once, the Court followed its prior interpretation of the state constitution even where the plaintiffs acquired the bonds at issue after the state court had rejected the Supreme Court interpretation and had declared the bonds unconstitutional. ${ }^{43}$ The Court in that case noted that the dispositive question was not the date of the bonds but the substantive question of their constitutionality. ${ }^{44}$

Sometimes the Court did not even pretend that the state constitutional law it ignored was in fiux. In 1873, for example, the Jus-

${ }^{37} 25$ Wis $167,181-82$ (1869).

${ }^{38} 83$ US 678, 689-90, 697-98 (1873).

s9 Id at 689 .

to Id at 689-90. See also Venice v Murdock, 92 US 494, 501 (1876) (characterizing previous New York court decisions, which held that certain bond transfers were invalid, as matters of "general law principles").

${ }^{4}$ See, for example, Pine Grove v Talcott, 86 US 666, 667 (1874); Taylor v Ypsilanti, 105 US 60, 70-71 (1882); New Buffalo v Iron Co., 105 US 73, 75-76 (1882); Burgess v Seligman, 107 US 20, 33-35 (1883); Venice v Murdock, 92 US 494, 501 (1876); and Douglass $v$ Pike City, 101 US 677, 686-87 (1880).

12 See, for example, Thompson v Perrine, 103 US 806, 816-19 (1881) (noting that recent state decision was irreconcilable with earlier ones, then stating that "independently of any such consideration, there are conclusive reasons why we cannot, in opposition to our own views of the law, as expressed in numerous cases, accept the principle of that case as decisive of the rights of the parties").

is Thompson $v$ Perrine, 106 US 589, 590-91 (1883) (second decision reaffirming the first between same hitigants but involving different bonds).

"Id. 
tices refused to follow prior Michigan Supreme Court rulings on the grounds that the Michigan cases "do not satisfy our minds" and left "unanswered" the questions raised in a dissent to one of the Michigan opinions. ${ }^{45}$ Similarly, in 1883, the Court rejected Missouri precedent because "in the exercise of that independent judgment which it is our duty to apply ... . we are forced to a different conclusion." quering new territory, over the vigorous dissent of such luminaries as Justice Oliver Wendell Holmes. ${ }^{47}$ Lower federal courts similarly applied federal law to many state questions well into the twentieth century. ${ }^{48}$

Thus in 1890, when Hans was decided, the Court had long since abandoned any pretense of limiting the Swift general law doctrine to matters of commercial law. Virtually any state decision, on any question of state substantive law, was fair game for federal rejection. In particular, the Court seemed most willing to ignore any possible distinction, in terms of the substantive law to be apphed, between federal question and diversity jursidiction, especially in cases involving state bonds, as in Hans itself. The Court, moreover, seemed untroubled by the threat its broadening of the Swift doctrine posed to state sovereignty. For example, in 1868 it affirmed a federal court's issuance of a writ of mandamus ordering state officials to levy a tax, despite an outstanding state court injunction ordering the officials not to levy the tax. ${ }^{49}$

4 Pine Grove, 86 US at 677.

16 Burgess, 107 US at 35 . State statutory and common law went by the wayside as well. In 1894, the Court, extending its "independent judgment" to the interpretation of a state statute, refused to follow a Wisconsin Supreme Court construction of the state's codified statute of limitations. Metcalfe $v$ Watertown, 153 US 671, 678-81 (1894). Again, after noting the general rule that federal courts were bound to follow state interpretations of state statutes, the Court decided that in the case at issue, "we think we are at liberty, and perhaps required ... to interpret this statute for ourselves." Id at 678-79. And by 1893, most questions of tort law were considered questions of general law and thus subject to federal common law. See, for example, Baltimore \& Ohio R.R. Co. v Baugh, 149 US 368, 370-71 (1893) and cases cited therein; Bridwell and Whitten, The Constitution and the Common Law at 119-22 (cited in note 23) (listing cases). In 1910, a case involving the sale of real estate was held to implicate general rather than local law. Kuhn v Fairmont Coal Co., 215 US 349, 361 (1910). Thus, with or without a statute, settled state court decisions were frequently ignored by the Court.

17 See Black \& White Taxicab Co. v Brown \& Yellow Taxicab Co., 276 US 518, 532-36 (1928) (Holmes dissenting). See also cases cited in Erie Railroad Co. $v$ Tompkins, 304 US 64, 75-76 and nn 11-18 (1938).

to See H. Parker Sharp and Joseph B. Brennan, The Application of the Doctrine of Swift v. Tyson Since 1900, 4 Ind L J 367 (1929).

49 Riggs $v$ Johnson County, 73 US 166, 195-96 (1868). There is no evidence that the 
The Court's consistent failure to respect the original limits of Swift during the latter half of the nineteenth century had profound consequences for its interpretation of the Eleventh Amendment. If the federal courts were exercising their "independent judgment" and applying federal substantive law in both diversity and federal question cases, there was indeed little reason to distinguish between the two types of jurisdiction. Thus, when the Hans Court examined the language of the Eleventh Amendment, it could not be expected to discern any reason for the amendment's apparent distinction between diversity and federal question jurisdiction; after the expansion of Swift, the substantive law that would be applied if the state were amenable to suit would be identical under either diversity or federal question jurisdiction. Both the Court's historical analysis-relying on the lack of any perceptible reason for the framers to have distinguished between diversity and federal question jurisdiction ${ }^{50}$-and its ultimate ruling were consistent with the contemporaneous view that federal courts sitting in diversity possessed significant freedom to decide substantive matters independently of state law. Indeed, any other ruling would have put Eleventh Amendment jurisprudence at odds with the bulk of the Court's Article III jurisprudence. Thus the legitimacy of Hans-independent of its historical accuracy-depends heavily on its relationship to the status of the distinction between the substantive law to be applied under diversity and federal question jurisdiction.

In 1938, Erie Railroad Co. $v$ Tompkins put an end not only to the expansion of the Swift doctrine but to Swift itself. ${ }^{51}$ The Court declared itself constitutionally bound to overrule Swift and to reinterpret the Rules of Decision Act to require federal courts to follow

Court's willingness to ride rougbshod over state decisions in diversity cases was based on any rejection of federalist principles of states' rights. See, for example, Slaughterhouse Cases, 83 US 36 (1873); United States v E.C. Knight Co., 156 US 1 (1895). Allowing federal court decisions to interfere with prior state decisions thus is not inconsistent with the Hans Court's unwillingness to subject states to further suits. Both doctrines appear to stem instead from the Court's vision of its own role (and that of the lower federal courts), and of the meaning of Article III as amended.

so The Court in Hans based its decision primarily on the ground that the original meaning of Article III, restored by the Eleventh Amendment after the distortion of Chisholm $v$ Georgia, 2 US 419 (1793) (allowing suit by South Carohna plaintiffs against State of Georgia), was to protect the states' preexisting sovereign immunity in all cases. The Court noted that suits against unconsenting states were "unknown to the law, and forbidden by the law" at the time of the adoption of the Constitution, and thus were "not contemplated by the Constitution." 134 US at 15.

${ }^{\text {s1 }} 304$ US 64, 79-80 (1938). 
state substantive law in all diversity cases. ${ }^{52}$ Since 1938, then, courts have made a sharp distinction between cases brought under diversity jurisdiction and cases brought under federal question jurisdiction. Only in the latter cases are the federal courts free to apply federal law.

Erie thus ravaged the Article III jurisprudence of Swift. Not one facet of the nineteenth-century views on the appropriate differences in sources of law in diversity and federal question cases remained unchanged. Whether Erie or Swift was the more accurate interpretation of the original meaning of Article III is debatable; ${ }^{53}$ that the two cases are absolutely incompatible is not.

This drastic change in the legal landscape calls into serious question the Hans Court's blurring of the distinction between diversity and federal question cases. It is the sort of change that justifies abandoning even estabhshed precedent. As noted earlier, departures from stare decisis are justified either where changed circumstances have so undermined the prior case as to deprive it of its legitimacy, or where later cases have revealed glaring inconsistencies in the law. Both factors counsel in favor of overruling Hans.

Because the legitimacy-to say nothing of the correctness-of Hans depended on its integration with the related constitutional theory of an expanded Swift doctrine, the Hans rule lost its legitimacy in 1938. Moreover, Erie not only compromised the historical accuracy of Hans, ${ }^{\text {s4 }}$ but also severed it from the Court's general

32 Id at 78.

ss There is a fair amount of scholarly dispute about whether Swift was a departure from prior expectations, either in its pronouncement about "general common law" or in its inclusion of commercial law within that category. Compare Bridwell and Whitten, The Constitution and the Common Law at 3 (cited in note 23); and W. Fletcher, 97 Harv L Rev at 1514 (cited in note 23), with Grant Gilmore, The Ages of American Law 33 (Yale, 1977); Morton J. Horwitz, The Transformation of American Law 245 (Harvard, 1977); and Charles Warren, New Light on the History of the Federal Judiciary Act of 1789, 37 Harv L Rev 49, 51-52 (1923). There is also some dispute about the modern meaning of the Rules of Decision Act, the statute construed in Swift. Compare Martin H. Redish, Federal Common Law, Political Legitimacy, and the Interpretive Process: An "Institutionalist" Perspective, 83 Nw U L Rev 761, 766-67 (1989) with Martha A. Field, Sources of Law: The Scope of Federal Common Law, 99 Harv L Rev 881, 924-27 (1986); Peter Westen, After "Life for Erie"-A Reply, 78 Mich L Rev 971, 982-89 (1980); Peter Westen and Jeffrey S. Lehman, Is There Life for Erie After the Death of Diversity?, 78 Mich L Rev 311, 356-59 (1980). These disputes are not relevant to my argument, which depends only on the fact that Swift was the law in 1890 and is so no longer.

s4 To the extent that Erie is historically more accurate than Swift (or at least than Swift's progeny), it suggests that the Hans Court missed the historical importance of the Eleventh Amendment's clear distinction between diversity and federal question cases. Akhil Amar has suggested that the Eleventh Amendment was in fact designed in part to correct 
Article III jurisprudence, leaving it a vestigial anomaly. Hans, justifiable (or at least understandable) when it was decided, now stands as the lone remainder of what was once an integrated and prevailing view of the interrelationship between diversity and federal question jurisdiction. As such, it is ripe for overruling.

the Chisholm Court's mistaken application of federal law to a state question (sovereign immunity) in a diversity suit. Amar, 96 Yale $L J$ at 1473-75 (cited in note 4). Amar's sophisticated analysis supports the thesis that Swift was incorrect as a inatter of constitutional interpretation, although it still does not justify departing from stare decisis by overruling Hans. One commentator has also made a rather confused argument that Erie, if historically correct, would demand that the federal courts apply the state's own law of sovereign immunity, and thus that had the Erie doctrine prevailed in 1793, Chisholm would not have been decided the way it was. Note, Interpreting the Ratifiers' Intent: The Burger Court's Eleventh Amendment Jurisprudence Reconsidered in the Light of Erie Railroad v. Tompkins, 66 Wasl U L Q 135, 157 (1988). 